\title{
Service Quality in Higher Education-A Case Study of Universiti Brunei Darussalam
}

\author{
Farooq Alani $^{1}$, Yasir Yaqoub ${ }^{1} \&$ Mahani Hamdan ${ }^{2}$ \\ ${ }^{1}$ Business Faculty, Sohar University, Sohar, Oman \\ ${ }^{2}$ Business School, UBD, Brunei \\ Correspondence: Farooq Alani, Business Faculty, Sohar University, Sohar, Oman. Tel: 968-9103-0074. E-mail: \\ falani@soharuni.edu.om
}

Received: November 14, 2014 Accepted: December 19, 2014 Online Published: March 30, 2015

doi:10.5539/ies.v8n4p231

URL: http://dx.doi.org/10.5539/ies.v8n4p231

\begin{abstract}
No one doubts the value and importance of quality education, and quality assurance is one major driving force to achieve this. Measuring the performance of service quality of education services of Universiti Brunei Darussalam (UBD), as part of the quality assessment, was assessed based on Parasuraman's five Servqual dimensions. The assessment was obtained from the undergraduates' perspectives across four faculties, and data was collected using e-questionnaire. The questionnaire was distributed to 400 students via email, but only 268 responded. Faculty-wise and university-wise rankings of the means of individual item scores from the questionnaire revealed some consistency in students' evaluation of quality at UBD. The analysis of variance findings rejected the hypothesis of equality of the mean scores across the four faculties of UBD. Post-hoc analysis and Tukey's Honestly Significant Difference (HSD) reported significant differences between 'science-based' and 'social sciences-based' students' needs and perception of quality. Overall, the results of the study showed that the quality of education services provided by UBD was only satisfactory among all students, rather than being exceptional. Teamwork, communication skills, creativity and innovation indicated by the students signaled the need of TQM implementation in UBD. The study also stressed the role of the university's administration and management to vigorously improve the quality of services they provide to the students and continue to increase the overall organisational performance.
\end{abstract}

Keywords: quality assurance, TQM, higher education, Brunei Darussalam

\section{Introduction}

Education is important because without education, there is no development. Education means more than just acquiring knowledge. Audrey Hepburn once said, "A quality education has the power to transform societies in a single generation, provide children with the protection they need from the hazards of poverty, labor exploitation and disease, and give them the knowledge, skills, and confidence to reach their full potential." Education without 'quality' therefore means no future for equality, freedom and sustainable human development. Quality education plays a big part in globalization. Global competition has brought to the fore the critical importance of quality education, and the demand for new competencies in today's information society. Following the trends in higher education, many academic institutions have recognised the central importance of quality not only in teaching but also in university management. They have increasingly embarked on a mission to improve their quality in order to remain competitive. Like business corporations, higher education institutions (HEIs) have become subject to regulatory and public reviews, and this has brought new urgency and commitment to the search for quality in higher education.

Although quality assurance and total quality management (TQM) are widely practiced in higher education (Vazzana, Backmann, \& Elfrink, 1997), there have been some conceptual and technical issues particularly the TQM implementation at HEIs, starting with the definition of quality, the applicability of TQM principles and tools, and the applicability of quality measurement and improvement devices such as performance indicators, accreditation, programme and institutional assessment and quality audits (Sarrico, Rosa, Teixeira, \& Cardoso, 2010). Regardless of the availability of quality standards (Aly \& Akpovi, 2001), assessing quality in higher education is inherently difficult to measure (Tsinidou, Gerogiannis, \& Fitsilis, 2010). Without a methodical approach and proper implementation, TQM efforts of HEIs are doomed to fail (Karapetrovic, Rajamani, \& 
Willborn, 1999). As pointed out by Birnbaum (2000), "TQM was sound; it was the implementation that was at fault" (p. 104).

Even though many universities around the globe have implemented TQM, it is difficult to draw any reliable conclusions about the popularity of TQM practices in Brunei universities, specifically Universiti Brunei Darussalam (UBD), the first national university in the country. In 2009, there has been a notable structural change to Brunei's education system called SPN-21 (Sistem Pendidikan Negara Abad ke 21), which strongly geared towards a quality education that responds to and fulfills the needs of a constantly evolving society in a globalized world full of uncertainty and challenges. Despite efforts by the government to make education accessible to all, access to quality education remains a major concern of HEIs. In the literature, the authors identified very few (if any) papers which describe the initiatives for attaining quality education of Brunei HEIs in general and UBD in particular (Ahmad \& Kifle, 2010; Haji-Rashid, 2007). No published research has so far tried to offer empirical studies on the quality of education services in Brunei HEIs. To address this limitation, the current paper seeks to assess the quality of education services in UBD.

\section{Literature Review}

Quality is not a new but a highly contested concept. It is a philosophical concept (Green, 1994) in which we cannot define it with precision. Until today, there is little agreement on what defines quality. McConville (1999) stated that there is no definition of quality but we will know it when we find it, meaning that quality is not only elusive (Neave, 1994), but also slippery and value laden (Harvey \& Green, 1993). Due to the lack of theory of quality and higher education is a service industry with no tangible product, definition of quality in higher education is even difficult to achieve (Scott, 1994). Moreover, higher education systems vary in different countries. Parri (2006) identified several approaches to the concept of quality of higher education: quality as exceptionality, excellence; zero errors; fitness for purpose; transformation and reshaping; threshold and enhancement. Of these approaches, the most commonly used definition of quality in higher education is quality as fitness for purpose. Ali and Shastri (2010) refers this to "fitting the customer specifications, minimum-based fitness for purpose and customer satisfaction" (p. 10). Based on this concept, an institution must define their goals in the mission statements, decide on to what extent their service or product meets the goals, and set the focus to meet the needs of the customers of higher education. Customers can be internal and external to the organisation, and Jabnoun (2002) identified that the key customers of HEIs are students and employers.

There are two main approaches to quality: quality assurance and total quality management (Jabnoun, 2002). Quality assurance (QA) is a systematic approach to the pursuit of quality (Collins, 1994). It is generally concerned with quality planning and defect prevention through systems and documented processes throughout the supply chain (Garvin 1988). Quality assurance is also about conformance of products, services and processes with given requirements and standards (Moreno-Luzon \& Peris, 1998) such as ISO 9000 series. The ISO 9000 series is the most common and popular set of standards of QA. TQM on the other hand is a comprehensive management approach aiming at satisfying or delighting customers (Moreno-Luzon \& Peris, 1998). The idea of satisfying customers' needs and expectations as part of quality raises the hackles among academics because HEIs have various interested parties with different views about its role (Houston, 2008). At institutional level, administrators may perceive students as customers of faculty but faculty staff may see this as a selling point of commercialisation (Ali \& Shastri, 2010). Thus, some authors suggest the term 'stakeholders' as it is more appropriate for use in educational institutions. TQM includes continuous improvement, customer satisfaction, empowerment and top management responsibility (Dean \& Bowen, 1994; Hartline \& Ferrell, 1996). It underlines the importance of quality culture in designing, producing and improving products and services. In this study however, we will not look into TQM. Despite the growing awareness of the importance of quality education in Brunei, we found that TQM has not been fully embraced in UBD. What has actually been taken place in UBD is quality assurance, but this also did not receive greater attention across faculty staff. There were several reasons for the lack of TQM implementation in UBD. The absence of quality culture, the cumbersome bureaucracy and the lack of effective communication in the organisation, but the main cause was the lack of strong commitment from top management. TQM also has a much broader meaning and involves multi-faceted processes.

In general, many universities have either become partially involved (meaning that HEIs are committed only to quality assurance) or totally involved in TQM implementation (Aly \& Akpovi, 2001). This study focuses on QA as it is more applicable to the context of the study. The study is conducted within the context of HEIs in Brunei Darussalam, particularly using the case study of Universiti Brunei Darussalam. Quality assurance (QA) is different from TQM in terms of its focus, nature, role of management, role of employees and main enablers (Jabnoun, 2002). QA focuses more on conformance with standards. It guarantees the improvement of standards 
and quality in higher education in order to make higher education meet the needs of students, employers and financiers (Lomas, 2002). QA is also static in nature and the role of management is mainly to establish documented systems, provide training and resources and supervise employees. Employees are participated in setting standards, searching for new improvement, checking performance and correcting actions. With respect to quality dimensions, HEIs have specific quality dimensions that reflect the type of services they provide such as teaching, research, learning, delivery mechanism, curriculum development, administrative services and infrastructure and facilities (Sahney, Banwet, \& Karunes, 2004).

Quality assurance is divided into two: external and internal. External QA refers to quality related assessments provided by different bodies or individuals outside the higher education institutions such as quality audit recognition and accreditation. The objective is to achieve accountability. Internal QA on the other hand aims at internal accountability and institutional development. It takes into account all institutional activities mainly on academic issues, and assesses the efficiency of activity and ways of ensuring quality within the institution (El-Khawas, 1998). QA is based on three principles: accountability, control and improvement (Harvey, 1999). Accountability refers to meeting the preferences of politicians, outside parties and financiers. Control indicates that the institution can control the expenditure of resources and achieve high quality with the existing resources. Improvement is to enable the institution to get necessary input, refine the process and raise the standards of output in order to meet the goals. What so typical about QA is quality assessment. The purpose of quality assessment in higher education is to improve all the activities within the institution and meet the needs of customers (Hernon, 2002). It also assesses to what extent the activity meets customers' expectations (or some prefer the term 'stakeholders') (see Diagram 1-UBD Strategic Plan).

Quality assessment entails quality that has been created by the institution, and the quality of service and customer satisfaction is largely part of the assessments. Quality can be examined from the stakeholders' perception of the degree to which the institution meets their expectations (Parasuraman, Zeithaml, \& Berry, 1988). Stakeholders encompass students, parents, employers and employees in the organisation (academic, administrative and support staff), industry and society as a whole. In this study however, the quality assessment of education services was obtained from the students' perspective as they are the key recipients of education services. Although there have been many approaches and instruments available for use to measure service quality, there is still no consensus on how best to measure and manage quality within HEIs. This is because education services are intangible and thus difficult to measure.

A number of studies in the literature developed their own instruments to assess quality, but there were still generally based on the existing Parasuraman et al.'s (1988) Servqual dimensions. For example, Tsinidou et al's (2010) quality instrument covered all the five dimensions of Servqual (Table 1) to measure the service quality of all departments in the School of Business and Economics, Technical Educational Institute of Larissa higher education, Greece. The assessment of the service quality was obtained from the perspective of undergraduate students with reference to seven quality criteria namely academic staff, administration services, library services, curriculum structure, location, infrastructure and career prospects. In this study, the Servqual model is employed to measure the five dimensions of service quality of UBD. We adopted Servqual model for two reasons. The model has often been used by researchers to assess the service quality of the organisation including HEIs, and secondly, Servqual and its alternative models such as SERVPERF and HEdPERF have been shown to present the best measurement capability (Brochado, 2009). 


\begin{tabular}{|c|c|c|c|c|c|c|}
\hline Vision & \multicolumn{6}{|c|}{$\begin{array}{l}\text { First class international university, Distinctive National Identity } \\
\text { Top } 50 \text { in Asia by } 2015\end{array}$} \\
\hline $\begin{array}{l}\text { Purpose \& } \\
\text { Values }\end{array}$ & \multicolumn{4}{|c|}{$\begin{array}{l}\text { Develop individuals and society by pushing back } \\
\text { frontiers of human knowledge through a conducive } \\
\text { environment, excellence in teaching, learning, } \\
\text { research, scholarship, public service and professional } \\
\text { practices }\end{array}$} & \multicolumn{2}{|l|}{$\begin{array}{l}\text { People } \\
\text { Expertise } \\
\text { Relevance } \\
\text { Leadership }\end{array}$} \\
\hline $\begin{array}{l}\text { Stakeholders } \\
\text { \& Partners }\end{array}$ & $\begin{array}{l}\text { Students: } \\
\text { Marketability; } \\
\text { Knowledge; } \\
\text { Flexibility; } \\
\text { Engaging enviror }\end{array}$ & ment & $\begin{array}{l}\text { Acade } \\
\text { Suppo } \\
\text { envirol } \\
\text { Person } \\
\text { Recog } \\
\text { Vibran }\end{array}$ & $\begin{array}{l}\text { nic Staff: } \\
\text { tive working } \\
\text { ament; } \\
\text { al growth; } \\
\text { hition; } \\
\text { t research culture }\end{array}$ & $\begin{array}{l}\text { Community: } \\
\text { Skills; } \\
\text { Expertise; } \\
\text { Innovation; } \\
\text { Responsibility; } \\
\text { Enterprising }\end{array}$ & $\begin{array}{l}\text { University as a } \\
\text { whole: } \\
\text { Prestige; } \\
\text { Reputation; } \\
\text { Ranking }\end{array}$ \\
\hline $\begin{array}{l}\text { Strategic } \\
\text { Pillars }\end{array}$ & $\begin{array}{l}\text { Continuously } \\
\text { teaching and } \\
\text { experience }\end{array}$ & $\begin{array}{l}\text { enhance } \\
\text { learning }\end{array}$ & $\begin{array}{l}\text { Motiva } \\
\text { develo } \\
\text { maxim }\end{array}$ & $\begin{array}{l}\text { ite learners to } \\
\text { um potential }\end{array}$ & $\begin{array}{l}\text { To generate } \\
\text { world-class } \\
\text { research }\end{array}$ & $\begin{array}{l}\text { Raise international } \\
\text { profile }\end{array}$ \\
\hline Strategic & \multicolumn{6}{|l|}{ Internal Process: } \\
\hline & \multicolumn{2}{|c|}{ Minimise bureaucracy } & \multicolumn{2}{|c|}{$\begin{array}{l}\text { Provide outstanding } \\
\text { facilities }\end{array}$} & $\begin{array}{l}\text { Increase and aid } \\
\text { collaborations } \\
\text { and partnerships }\end{array}$ & $\begin{array}{l}\text { Continuous } \\
\text { evaluation and } \\
\text { improvement of } \\
\text { organisational } \\
\text { performance }\end{array}$ \\
\hline & \multicolumn{4}{|l|}{ Finance: } & \multicolumn{2}{|l|}{ People: } \\
\hline & \multirow[t]{2}{*}{$\begin{array}{l}\text { Effective fund } \\
\text { management }\end{array}$} & \multirow{2}{*}{\multicolumn{2}{|c|}{$\begin{array}{l}\text { To acquire } \\
\text { alternative } \\
\text { source } \\
\text { funding }\end{array}$}} & \multirow[t]{2}{*}{$\begin{array}{l}\text { To grow the } \\
\text { university } \\
\text { endowment }\end{array}$} & $\begin{array}{l}\text { Develop } \\
\text { leadership and } \\
\text { innovation in our } \\
\text { people }\end{array}$ & $\begin{array}{l}\text { Promote effective } \\
\text { communication }\end{array}$ \\
\hline & & & & & $\begin{array}{l}\text { Support staff } \\
\text { development }\end{array}$ & $\begin{array}{l}\text { Attract, retain and } \\
\text { recognize }\end{array}$ \\
\hline
\end{tabular}

Diagram 1. UBD strategic plan

Table 1. Servqual five dimensions

\begin{tabular}{ll}
\hline Dimensions & Definition \\
\hline 1. Tangibles & $\begin{array}{l}\text { The appearance of physical facilities, equipment, support services and service } \\
\text { personnel. }\end{array}$ \\
2. Reliabiilty & $\begin{array}{l}\text { The degree to which the knowledge, skills learned and services are offered } \\
\text { accurately, dependably and on time without errors. }\end{array}$ \\
3. Responsiveness & $\begin{array}{l}\text { This refers to willingness to help customers and meet their needs and wants. In } \\
\text { difficult situations, it is also the ability to respond effectively. }\end{array}$ \\
\hline
\end{tabular}


4. Assurance The confidence and trust that the customers hold towards the institute and the feeling of safety in case of danger.

5. Empathy The attention and care that the institution may offer to customers. This part also refers to convenient operating hours.

\section{Methods}

A questionnaire was designed with reference to Parasuraman et al.'s five dimensions, but with several modifications to suit the following quality criteria namely Faculty staff (academic and administrative staff), curriculum structure, library services and the physical environment of UBD (Appendix 1). A five-Likert rating scale from 1 (strongly disagree) to 5 (strongly agree) was used to assess all of the statements in the questionnaire except for the overall quality of educational services of UBD. The questionnaire was conducted for two weeks only that is from mid to end of March, 2013. The questionnaire was sent out to about 400 undergraduates by email across four faculties: Faculty of Business, Economics and Policy Studies (FBEPS), Faculty of Arts and Social Sciences (FASS), Faculty of Science (FOS) and Pengiran Anak Puteri Rashidah Sa'adatul Bolkiah Institute of Health Sciences (PAPRSBIHS). Out of 400, only 268 (67 percent response rate) replied and completed the questionnaire. The sample comprised of 94 (35 percent), 64 (24 percent), 75 (28 percent) and 35 (13 percent) undergraduates from FBEPS, FASS, FOS and PAPRSBIHS respectively.

\section{Results}

Based on the questionnaire, the study categorized several items into five servqual dimensions: tangible, reliability, responsiveness, assurance and empathy. Tangible with five items (item no. 22,23and 25), reliability with three items (item no. 1, 11 and 16), responsiveness with three items (item no. 3,9and 18), empathy with two items (item no4 and 12), and assurance with only one item (item no. 26).

\subsection{Tangible}

The tangible aspect was assessed in terms of library facilities and UBD's overall quality environment. With respect to library facilities including computer labs, study rooms and reading areas, only 7 percent disagreed with the adequacy of facilities provided by UBD library, 37 percent indicated that they were neutral, and 35 percent showed their agreement (Diagram 2). As for quality environment that is the comfort of students to study in the library, many respondents indicated neutral (40 percent), whilst 27 percent agreed and the other 20 percent disagreed that UBD library had provided them quality environment.

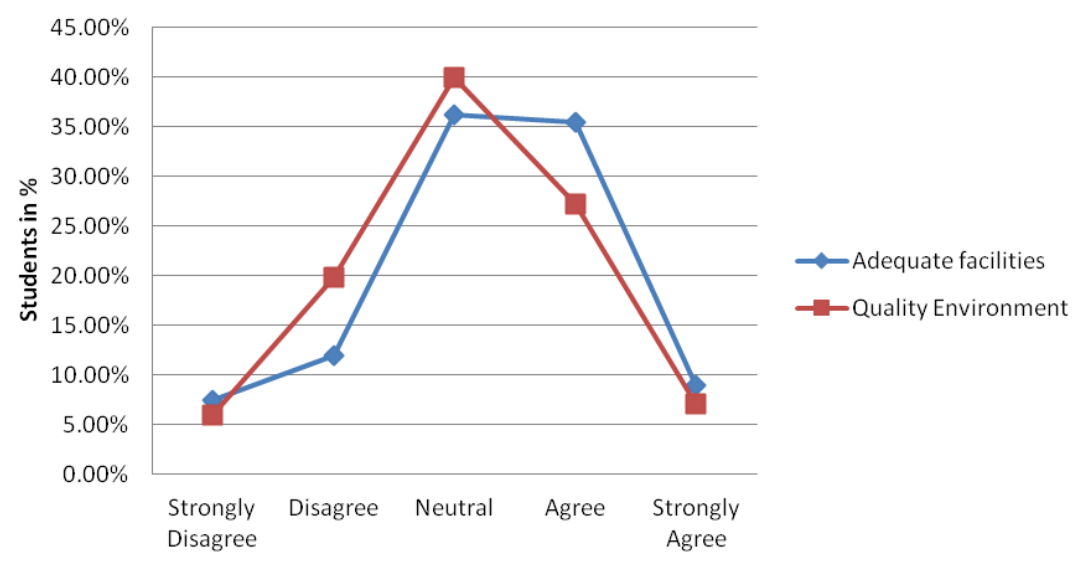

Diagram 2. Tangible-UBD library

Diagram 3 showed the tangible aspect of UBD in terms of quality environment for studying, the availability of necessary equipment and the level of cleanliness around campus. Most students responded neutral for all these aspects that is 38,41 and 38 percents in that order. Although there had been some agreements from students on the UBD's quality environment for studying ( 25 percent) and the quality of equipments being provided (28 percent), 31 percent of them opposed that UBD provides high level of cleanliness. 


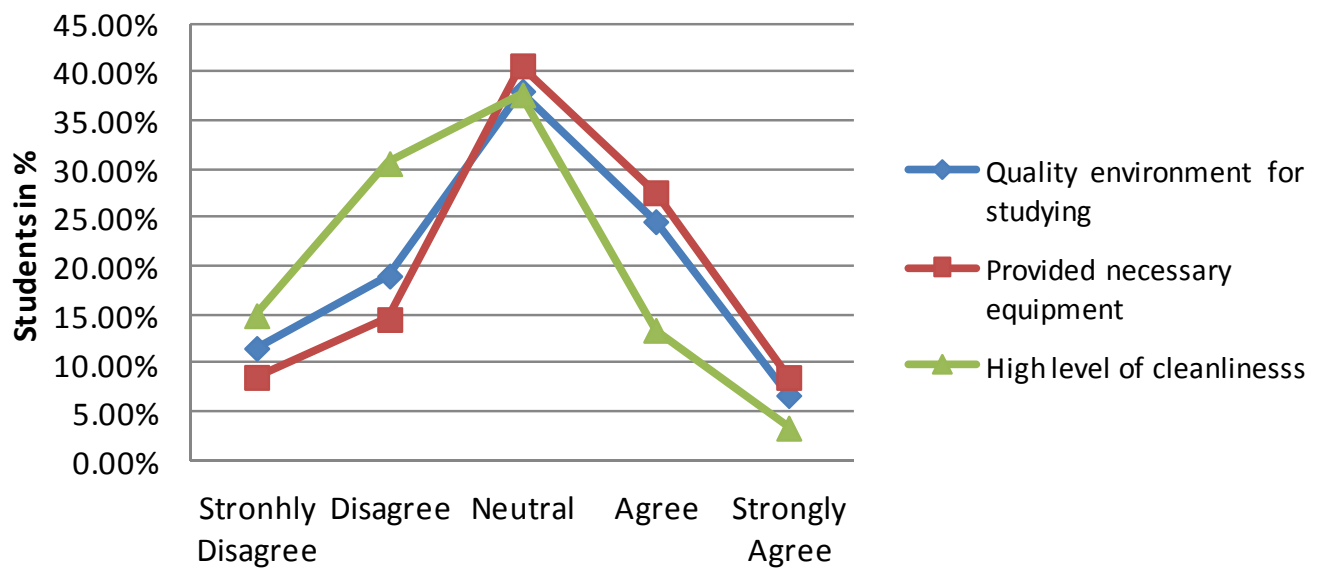

Diagram 3. Tangible-UBD

\subsection{Reliability}

Reliability refers to the level of accurate information on GENnext Program provided by Faculty staff (which includes both academic and administrative staff) to all students. Notably, whilst between 30 and 40 percent of respondents agreed that GENnext program was useful and information provided by their lecturers had benefited them, the reliability of information from administrative staff was found to be unsatisfactory as 31 percent of respondents disagreed that the administrative staff have had provided them with accurate information and the staff being efficient in providing useful information (Diagram 4). Overall, despite the well-sustained involvement of lecturers in improving the quality of their services, what still lacking in UBD is the efficiency and effectiveness of administrative staff in providing reliable services. This is among the limitations the study has to address in order to achieve high quality of education services in UBD and also for a successful TQM implementation, possibly in the future.

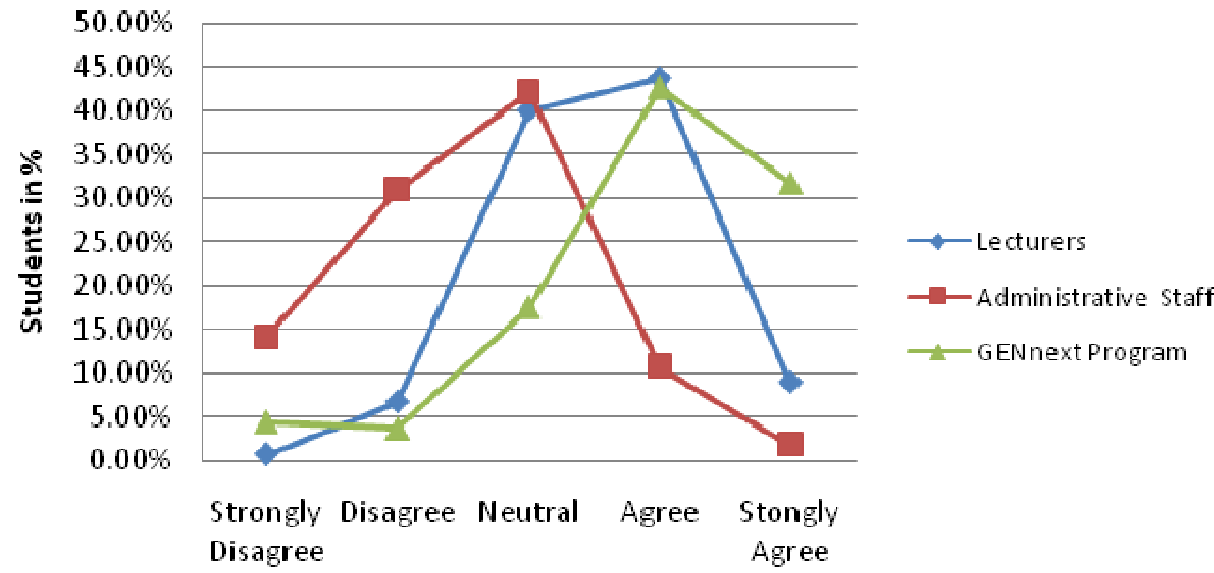

Diagram 4. Reliability

\subsection{Responsiveness}

Responsiveness was assessed with respect to the level of assistance given by the lecturers and administrative staff to the students. Respondents' agreement towards the level of lecturers' responsiveness (43 percent) was slightly higher compared to the level of responsiveness provided by administrative staff (12 percent) and librarians (25 percent) (Diagram 5). Administrative staff in this case was also poorly assessed by the students. About 29 percent of them disagreed that administrative staff were supportive. 


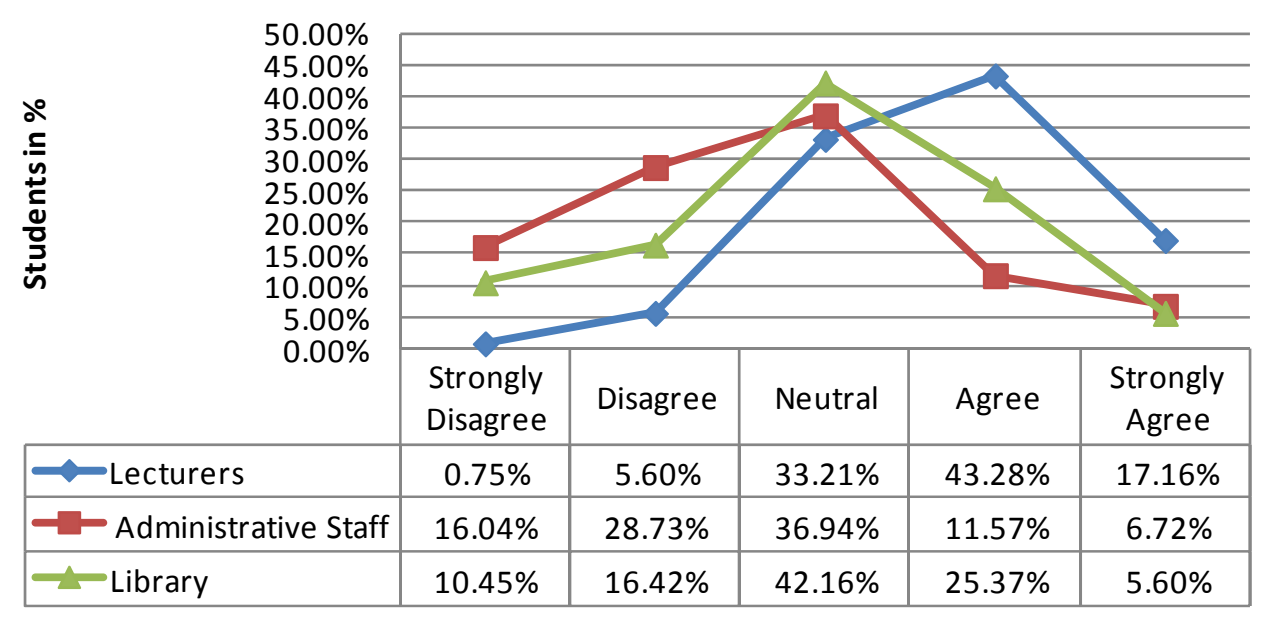

Diagram 5. Responsiveness

\subsection{Assurance}

The study obtained the students' perspective on the overall quality of education services provided by the university to assess the assurance dimension. Assurance acts as a trust being placed among students. Diagram 6 showed that nearly 46 percent of respondents were satisfied with the quality of education services provided by UBD. Although 29 percent had rated the quality of education services of UBD as good, it is important to note that the university is still far from being excellent.

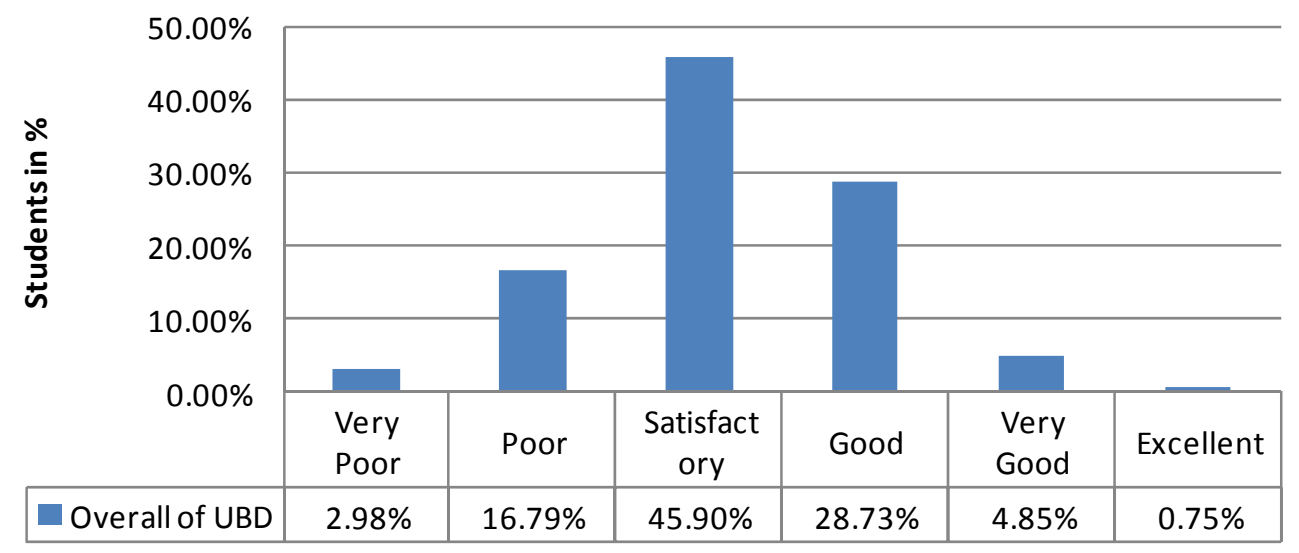

Diagram 6. Overall of UBD

\subsection{Empathy}

Empathy is an act of care and attention given by the faculty staff to the students. Based on Diagram 7, the result showed that there had been some disagreement on the accessibility of administrative staff. Similar result was also found in the ratings for the lecturers, but that level of disagreement was not as strong as for the faculty's administrative staff. About 44 percent of the respondents opposed that the administrative staff were easily accessible at times. Moreover, there was considerable amount of collective views from the students that the lecturers showed greater empathy feelings towards them than the administrative staff, and above 30 percent of them indicated that they were neutral about this aspect. 


\section{Lectureres Administrative Staff}

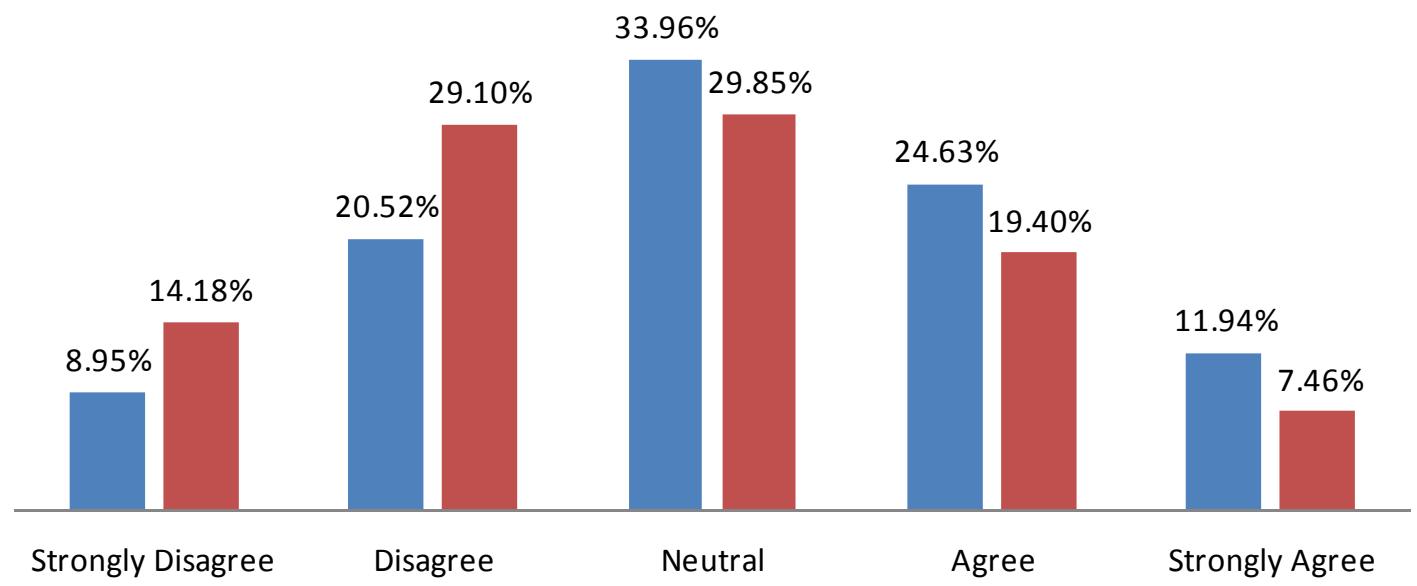

Diagram 7. Empathy

\subsection{Item Mean Scores Analysis}

Summary statistics for the overall mean scores by faculty are depicted in Table 2 and diagram 8 below.

Table 2. Overall mean score by faculty

\begin{tabular}{lcccc}
\hline Faculty & $\mathrm{N}$ & Mean & Std. Deviation & Std. Error \\
\hline FBEPS & 25 & 2.9656 & .33800 & .06760 \\
FASS & 25 & 2.9864 & .56920 & .11384 \\
FOS & 25 & 3.3568 & .36859 & .07372 \\
PAPRBS & 25 & 3.1376 & .41113 & .08223 \\
Total & 100 & 3.1116 & .45260 & .04526 \\
\hline
\end{tabular}

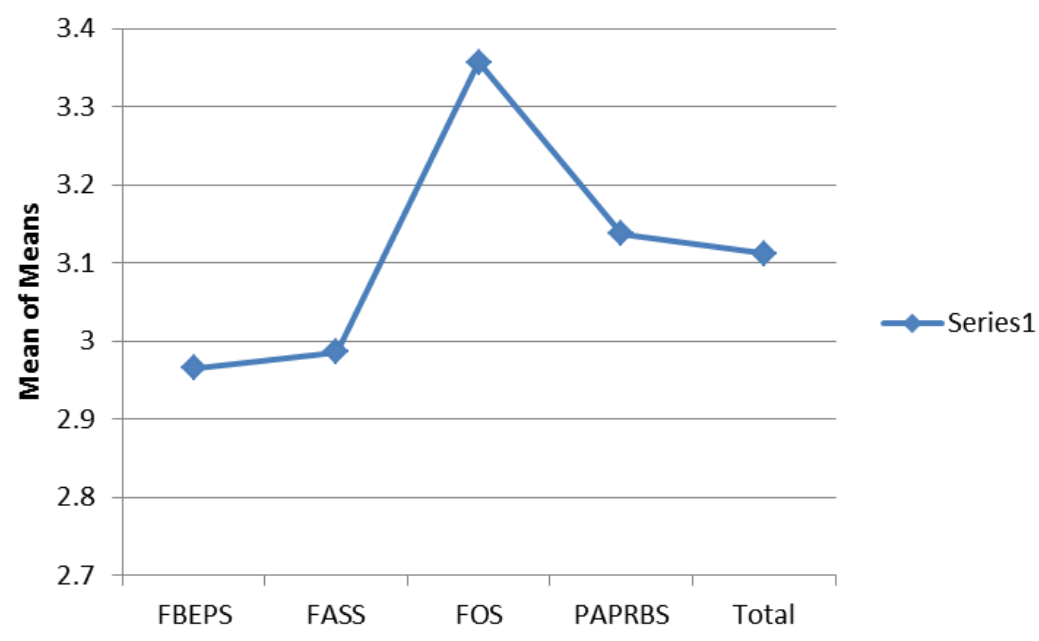

Diagram 8. Mean scores plot

The mean of individual item scores from the questionnaire based on the university-wise (all faculties) ranking depicted in Table1 below showed that in the aspect of lecturers and UBD GENnext program dimension (items 16, 
3, 7 and 1), this has got the highest ranking whereas scores related to administrative staff and level of cleanliness (items 9,11 and 25) were the least ranked. The mean of individual item scores that based on faculties' rankings (Tables 2, 3, 4 and 5) revealed, more or less the same conclusions derived from the University-wise ranking of Table 1.

The faculties' questionnaire data that are summarised in Table 2 and Diagram 8 above were used to conduct Analysis of Variance to test the hypothesis of equality of the mean scores across the four faculties of UBD (FBEPS, FASS, FOS and PAPRBS). Results of the analysis are depicted in Tables 3, 4 and 5 below.

Table 3. ANOVA

\begin{tabular}{lccccc}
\hline & Sum of Squares & Df & Mean Square & F & Sig. \\
\hline Between Groups & 2.445 & 3 & .815 & 4.386 & .006 \\
Within Groups & 17.835 & 96 & .186 & & \\
Total & 20.280 & 99 & & & \\
\hline
\end{tabular}

Table 4. Multiple comparisons

\begin{tabular}{|c|c|c|c|c|c|c|}
\hline \multirow{2}{*}{ (I) Factor } & \multirow{2}{*}{ (J) Factor } & \multirow{2}{*}{ Mean Difference (I-J) } & \multirow{2}{*}{ Std. Error } & \multirow{2}{*}{ Sig. } & \multicolumn{2}{|c|}{ 95\% Confidence Interval } \\
\hline & & & & & Lower Bound & Upper Bound \\
\hline \multirow[t]{3}{*}{ FBEPS } & FASS & -.0208 & .12191 & .998 & -.3395 & .2979 \\
\hline & FOS & $-.3912^{*}$ & .12191 & .010 & -.7099 & -.0725 \\
\hline & PAPRBS & -.1720 & .12191 & .496 & -.4907 & .1467 \\
\hline \multirow[t]{3}{*}{ FASS } & FBEPS & .0208 & .12191 & .998 & -.2979 & .3395 \\
\hline & FOS & $-.3704^{*}$ & .12191 & .016 & -.6891 & -.0517 \\
\hline & PAPRBS & -.1512 & .12191 & .603 & -.4699 & .1675 \\
\hline \multirow[t]{3}{*}{ FOS } & FBEPS & .3912 & .12191 & .010 & .0725 & .7099 \\
\hline & FASS & .3704 & .12191 & .016 & .0517 & .6891 \\
\hline & PAPRBS & .2192 & .12191 & .281 & -.0995 & .5379 \\
\hline \multirow[t]{3}{*}{ PAPRBS } & FBEPS & .1720 & .12191 & .496 & -.1467 & .4907 \\
\hline & FASS & .1512 & .12191 & .603 & -.1675 & .4699 \\
\hline & FOS & -.2192 & .12191 & .281 & -.5379 & .0995 \\
\hline
\end{tabular}

* The mean difference is significant at the .05 level.

Table 5. Homogeneous subsets

\begin{tabular}{lccc}
\hline \multicolumn{4}{l}{ Means } \\
\hline \multicolumn{3}{l}{ Tukey HSD $^{\mathrm{a}}$} \\
\hline Factor & $\mathrm{N}$ & \multicolumn{2}{c}{ Subset for alpha $=.05$} \\
\cline { 3 - 4 } & & 1 & 2 \\
\hline FBEPS & 25 & 2.9656 \\
FASS & 25 & 2.9864 & \\
PAPRBS & 25 & 3.1376 & 3.1376 \\
FOS & 25 & & 3.3568 \\
Sig. & \multicolumn{2}{c}{.496} & \\
\hline
\end{tabular}

Means for groups in homogeneous subsets are displayed.

${ }^{\mathrm{a}}$ Uses harmonic mean sample size $=25.000$. 
Table 3 shows that the null hypothesis of equality of the mean scores across the four faculties of UBD was rejected (p-value=.006). Post-hoc analysis and Tukey's Honestly Significant Difference (HSD) (Tables 8and 5) revealed that the mean score of FOS (3.36) was different from those of FBEPS (2.97) and FASS (2.99) at the 5\% level of significance, but that the difference between FOS and PAPRBS (3.14) scores was not statistically significant.

\section{Discussion}

The study has met its research objective that is assessing the quality of education services of HEIs in Brunei that is using UBD as a case study. Result of the study showed that the quality of education services of UBD was only satisfactory, and is still far from being excellent. With regards to the tangible aspect of quality, the study received many neutral responses from the students and at the same time, there was more agreement to this dimension indicating that UBD as a whole has reasonably provided adequate facilities and all the necessary resources, and quality environment for the students. Despite the positive feedback from the students, the university via the role of its Estate Department must set up a proper and control and monitoring system. This is to examine and ensure that all equipments and resources that are available such as computers, tables and projectors can put to good use as the authors still found equipments laying around in some office rooms. If an equipment is no longer functioning properly, then it should be quickly repaired or dispose appropriately. Notably, although UBD has outsourced cleaning services to a professional cleaning company which expected to be better than in-house, the university's poor level of cleanliness especially the lavatories and dormitories certainly requires greater attention. The university should be more stringent with this and conduct regular check-ups and provide clear university's expectations and guidelines to the company. This is a very important element for maintaining sufficient personal hygiene and stable learning environment for the students, and also for the university to establish its reputation and maintain regional and international exchange visits.

The results of the ANOVA and post-hoc analysis suggests that Faculty of Science (FOS) and Institute of Health Science (PAPRBS)students are, on the average, more satisfied with the quality environment of the University than the students of Business Faculty (FBEPS) and Faculty of Arts and Social science (FASS). This might be interpreted as a variation between 'science-based' and 'social sciences-based' students' needs and perception of quality. It might be worthwhile for the University management to investigate the specific needs of the social science-based students with respect to quality education.

Different from the academic staff, administrative staff did not appear to be very efficient in giving useful and accurate information and they were also not responsive to students' needs. They had hardly been there for them partly because they were not motivated to help students. There was lack of responsive learning environment culture in UBD-a culture that not only disseminates and receives information but also shapes the thinking process of groups and individuals (Deming, 2000; Senge, 2006). The university needs transformational leadership who can lead to positive changes in those who follow and a strong quality culture. Quality culture however can be difficult to achieve in HEIs because academic culture is non receptive. The culture is resistant "to quality process improvement from professors who think it is just another business-oriented fad" (Massy, 2003, p. 165), and resistant to quality terms and concepts, principles and practices. Thus, quality is not just about conforming to requirements and standards but also to some extent cultural changes (Yeh, 2003). It has been very difficult to compromise between quality and the traditions, values and purposes of HEIs (Birnbaum, 2000) because HEIs are generally influenced by its structural and traditional characteristics.

UBD needs to create a learning environment that is fair, engaging, motivating and comfortable, accessible, challenging and appropriate, and empathy from lecturers as well as administrative and other support staff were also vital to the quality of education services in HEIs. The university's management is responsible to reduce the level of bureaucracy (cut out unnecessary paperwork and duplication within the organisation), increase transparency and ensure that information is communicated effectively across faculties and among students and staff. Moreover, giving enough accurate and reliable information often boils down to a matter of trust. The university should honour the student trust placed in it and accept the responsibility to transmit knowledge and promote understanding. Indeed, QA is the trust of conformance of a product against requirements and standards. In terms of assurance dimension, the quality of education services was satisfactory rather than being excellent. This indicates that the quality of student learning in UBD has much more room for improvement in preparing students for the workplace including the university's teaching and research facilities, learning resources, physical infrastructure, health and safety policies and procedures and human resource management.

The study has several implications. To foster quality culture in Brunei's HEIs, it requires authoritative definition of quality, but this is not possible. Quality assurance must be developed as institutional policy and strategy for 
continuous improvement of university staff. UBD's top management level must first commit and gain full support from all members involved. Given that most HEIs are organised on departmental units, teamwork and communication between and across departments are necessary (Ali \& Shastri, 2009). The study also suggests a quality framework which is more adaptable to individual contexts. In other words, there is no 'one size fits all' in implementing QA or TQM framework. Students are also now being more selective based on their graduate employment prospects and becoming more selective about their study options. They increasingly open to studying on full-degree programs abroad. Competition in the education services industry may make universities more efficient and responsive and possibly more innovative. Nevertheless, too much competition would reduce institutional diversity, reinforce the existing bureaucratic structure as the university's administration is still subject to the authority of Ministry of Education, and damage wider participation which somewhat threaten the quality of education services of UBD. UBD's GENnext program requires a regular review to ensure its relevance in the job industry, and in this study, the students have indicated their strong interest to acquire teamwork management, communications, creativity and learning and innovation skills. Further research could be to suggest an appropriate quality assurance framework for UBD, and the quality assessment of education services could be done not merely on the organisational factors but also individual factors contributing to quality.

The university must start implementing QA control to measure and analyse the performance of its services. Quality assessment 'Student Feedback Exercise' which has often been practiced by UBD for many years is conducted at the end of every semester. The aim of this exercise is to help the university to improve the modules taken by the students and assist the lecturers to improve their teaching skills. This exercise has two limitations. Firstly, it focuses on the quality of teaching and learning, but not library services and the university's physical environment, and secondly, although feedback from students is an essential component of any pedagogic process, there is no feedback loop. When this happens, there is no way lecturers can improve as feedback needs to be integrated into the learning process and they have to act upon it. We suggest UBD to improve this online exercise, letting staff to access the students' feedback, and more importantly, be more transparent with staff performance evaluation system. This will allow the university to reach its goals and staff will therefore become more aware and careful in performing their duties and tasks. Training can help the university to improve and strengthen the quality of their administrative services. As presented in the results section, administrative staff is the weakest link in achieving high quality in UBD. Despite what so-called the information age, we were informed that information reaches out to them either late or slow due to poor communication among the levels of management. Consultation (face to face communication) can also help to alleviate work related problems faced by the administrative staff such as time management and communication skills.

The university recently sets up Office of Planning and Development (OPD), which is responsible in planning to achieve the UBD's vision-that is becoming the top 50 university in Asia. The Office ensures the presence of quality assurance and strives to achieve both national and international recognitions and accreditations for all the programs offered by UBD. Certainly, this takes time but QA itself is a process-centered approach. It focuses on improving the process that is used to create the end result, rather than on the result itself. The university therefore has to put in a lot of effort towards continuous improvement.

We received good cooperation from students throughout the data collection period, and to attain a sample size of 268 within two weeks without giving any reward or gift in return was completely unexpected. We sent gentle reminders every three days to the students to reply to us with completed questionnaire. For future research, it is suggested that respondents are to be segregated not only by faculties alone but also by gender and academic levels, assess the quality of education services of UBD from the perspectives of other stakeholders such as postgraduates, alumni and faculty staff, and to incorporate qualitative and quantitative methods in a single study such as interviews or focus groups to obtain deep insight about individuals' perception on the quality of education services of UBD. Finally, this study has made two significant contributions to the literature. Firstly, the issue of quality of UBD has been addressed from a student perspective as most studies do not look at this in the context of Brunei's higher education sector, and secondly, to the researchers' knowledge, although there has been a growing number of studies dealing with quality in higher education, very few (if any) of the studies were examined in Asia context particularly Brunei. Studies on quality in higher education were largely conducted in western countries and there were based on either qualitative or empirical data, but not both (Al-Tarawneh \& Mubaslat, 2011; Tsinidou et al., 2010; Vanagas \& Vilkas, 2008).

\section{Conclusion}

Overall, the quality of education services in UBD was rather satisfactory. Although the university is still far away from being excellent, it has achieved remarkable progress and development in almost every aspect. It might be worthwhile for the University management to further investigate the specific perception and needs of the social 
science-based students with respect to quality education. It is important for the university to continuously making improvements and attain high quality assurance program. The university should also start take a closer look at the total quality management of their services and find ways to satisfy stakeholders by producing high-quality products and services as quality assurance is just the first step towards implementing TQM. To implement these quality approaches (both QA and TQM) effectively, it certainly requires uniform commitment from all levels of university's management and promotes an institutional quality culture that is fit for purpose and takes account of institutional diversity which has existed across the globe.

\section{Acknowledgments}

We acknowledge and respect the good work of our research students for conducting the survey: Amy Thien Sook Ling, Liew Pei Ting, Chua Yi Shien, Salyani Takdir, Michelle Goh Siew Chien, and Sung Hui Yee.

\section{References}

Ahmad, A., \& Kifle, H. (2010). Brunei Darussalam: quality assurance in higher education (Country Report). $18^{\text {th }}$ SEAMEORIHED Governing Board Meeting, Bangkok, Thailand.

Ali, M., \& Shastri, R. K. (2010). Implementation of total quality management in higher education. Asian Journal of Business Management, 2(1), 9-16.

Al-Tarawneh, H. A., \& Mubaslat, M. (2011). The implementation of total quality management (TQM) on the higher educational sector in Jordan. International Journal of Industrial Marketing, 1(1), 1-10.

Aly, N., \& Akpovi, J. (2001). Total quality management in California public higher education. Quality Assurance in Education, 9(3), 127-131. http://dx.doi.org/10.1108/09684880110399077

Birnbaum, R. (2000). Management fads in higher education. Where they come from, what they do, why they fail. San Francisco: Jossey-Bass Inc.

Brochado, A. (2009). Comparing alternative instruments to measure service quality in higher education. Quality Assurance Education, 17(2), 174-190. http://dx.doi.org/10.1108/09684880910951381

Collins, P. (1994). Approaches to quality. The TQM Magazine, 6(3), 39-43. http://dx.doi.org/10.1108/09544789410057881

Dean, J. W., \& Bowen, D. E. (1994). Management theory and total quality: improving research and practice through theory development. Academy of Management Review, 9(3), 392-418. http://dx.doi.org/10.2307/258933

Deming, W. E. (2000). Out of the crisis (Rev. ed.). Cambridge, MA: MIT Press.

El-Khawas, E. (1998). Accreditation's role in quality assurance in the United States. Higher Education Management, 10(3), 43-56.

Garvin, D. A. (1988). Managing quality: The strategic and competitive edge. New York: Free Press.

Green, D. (1994). Trends and issues. In A. Craft (Ed.), International developments in assuring quality in higher education. London: The Falmer Press.

Haji-Rashid, F. R. (2007). Integrating strategic quality management in the context of corporate strategy-intial lessons: A case study of Universiti Brunei Darussalam. Special (Refereed) Volume on Quality Initiatives \& Practices in Higher Education published by the Quality Assurance Management Unit of the University of Malaya University of Malaya, Kuala Lumpur.

Hartline, M. D., \& Ferrell, O. C. (1996). The management of customer-contact service employees: An empirical investigation. Journal of Marketing, 60(4), 52-70. http://dx.doi.org/10.2307/1251901

Harvey, L. (1999). An assessment of past and current approaches to quality in higher education. Australian Journal of Education, 43(3), 237-255.

Harvey, L., \& Green, D. (1993). Defining quality. Assessment and Evaluation in Higher Education, 18(1), 9-34. http://dx.doi.org/10.1080/0260293930180102

Hernon, P. (2002). Quality: New directions in the research. Journal of Academic Liberianship, 28(4). http://dx.doi.org/10.1016/S0099-1333(02)00286-0

Houston, D. (2008). Rethinking quality and improvement in higher education. Quality Assurance in Education, 16(1), 61-79. http://dx.doi.org/10.1108/09684880810848413

Jabnoun, N. (2002). Control processes for total quality management and quality assurance. Work Study, 51(4), 
182-190. http://dx.doi.org/10.1108/00438020210430733

Karapetrovic, S., Rajamani, D., \& Willborn, W. W. (1999). University, Inc. Quality Progress (May), 87-95.

Lomas, L. (2002). Does the development of mass education necessarily mean the end of quality. Quality in Higher Education, 8(1), 71-79. http://dx.doi.org/10.1080/13538320220127461

Massy, W. F. (2003). Honoring the trust. Quality and cost containment in higher education. Bolton: Anker Publishing.

McConville, G. (1999). Everybody wants quality education: but what does it mean? Australian Universities' Review, 42(2), 2-4.

Moreno-Luzon, M. D., \& Peris, F. J. (1998). Strategic approaches, organisational design and quality management-integration in a fit and contingency model. International Journal of Quality Science, 3(4), 328-347. http://dx.doi.org/10.1108/13598539810243667

Neave, G. (1994). The politics of quality: Developments in higher education in Western Europe 1992-1994. European Journal of Education, 29(2), 115-134. http://dx.doi.org/10.2307/1561636

Parasuraman, A., Zeithaml, V. A., \& Berry, L. L. (1988). SERVQUAL: A multiple item scale for measuring consumer perceptions of services quality. Journal of Retailing, 64(1), 12-40.

Parri, J. (2006). Quality in higher education. Vadyba/Management, 2(11), 107-111.

Sahney, S., Banwet, D. K., \& Karunes, S. (2004). Conceptualising total quality management in higher education. The TQM Magazine, 16(2), 145-159. http://dx.doi.org/10.1108/09544780410523044

Sarrico, C. S., Rosa, M. J., Teixeira, P. N., \& Cardoso, M. F. (2010). Assessing quality and evaluating performance in higher education: Worlds apart or complementary views? Minerva, 48, 35-54. http://dx.doi.org/10.1007/s11024-010-9142-2

Scott, P. (1994). Recent developments in quality assessment in GB. In D. F. Westerheijden, J. Brennan, \& P. Maasen (Eds.), Changing contexts of quality assessment: recent trends in West European higher education (Netherlands, CHEPS).

Senge, P. (2006). The fifth discipline: The art and practice of the learning organisation (Rev. ed.). New York, NY: Doubleday.

Tsinidou, M., Gerogiannis, V., \& Fitsilis, P. (2010). Evaluation of the factors that determine quality in higher education: An empirical study. Quality Assurance in Education, 18(3), 227-244. http://dx.doi.org/10.1108/09684881011058669

Vanagas, P., \& Vilkas, M. (2008). Development of total quality management in Kaunas University of Technology. Engineering Economics, 4(59), 67-75.

Vazzana, G., Backmann, D., \& Elfrink, J. (1997). Does higher education practice what it teaches? Quality Progress, 30(12), 67-70.

Yeh, Y. F. (2003). Implementing a sustainable TQM system: Employee focus. TQM implementation, 15(4), 257-265. http://dx.doi.org/10.1108/09544780310486164

\section{Appendix}

\section{Sample of Questionnaire}

The aim of this questionnaire is to assess the quality of the education services in UBD in achieving student satisfaction particularly with respect to the quality of teaching and learning. Your individual answers will remain anonymous. If you have any questions about this or anything else about the survey, please do not hesitate to ask us. We appreciate your time to complete the following survey:
Faculty:
FBEPS
FOS
FASS
PAPRBS

Part A: Academic staffs

\begin{tabular}{|l|l|l|l|l|l|l|}
\hline & Please tick in one of the columns: & $\begin{array}{l}\text { Strongly } \\
\text { disagree }\end{array}$ & Disagree & Neutral & Agree & $\begin{array}{l}\text { Strongly } \\
\text { agree }\end{array}$ \\
\hline 1) & Lecturers are always highly efficient in providing & & & & & \\
\hline
\end{tabular}




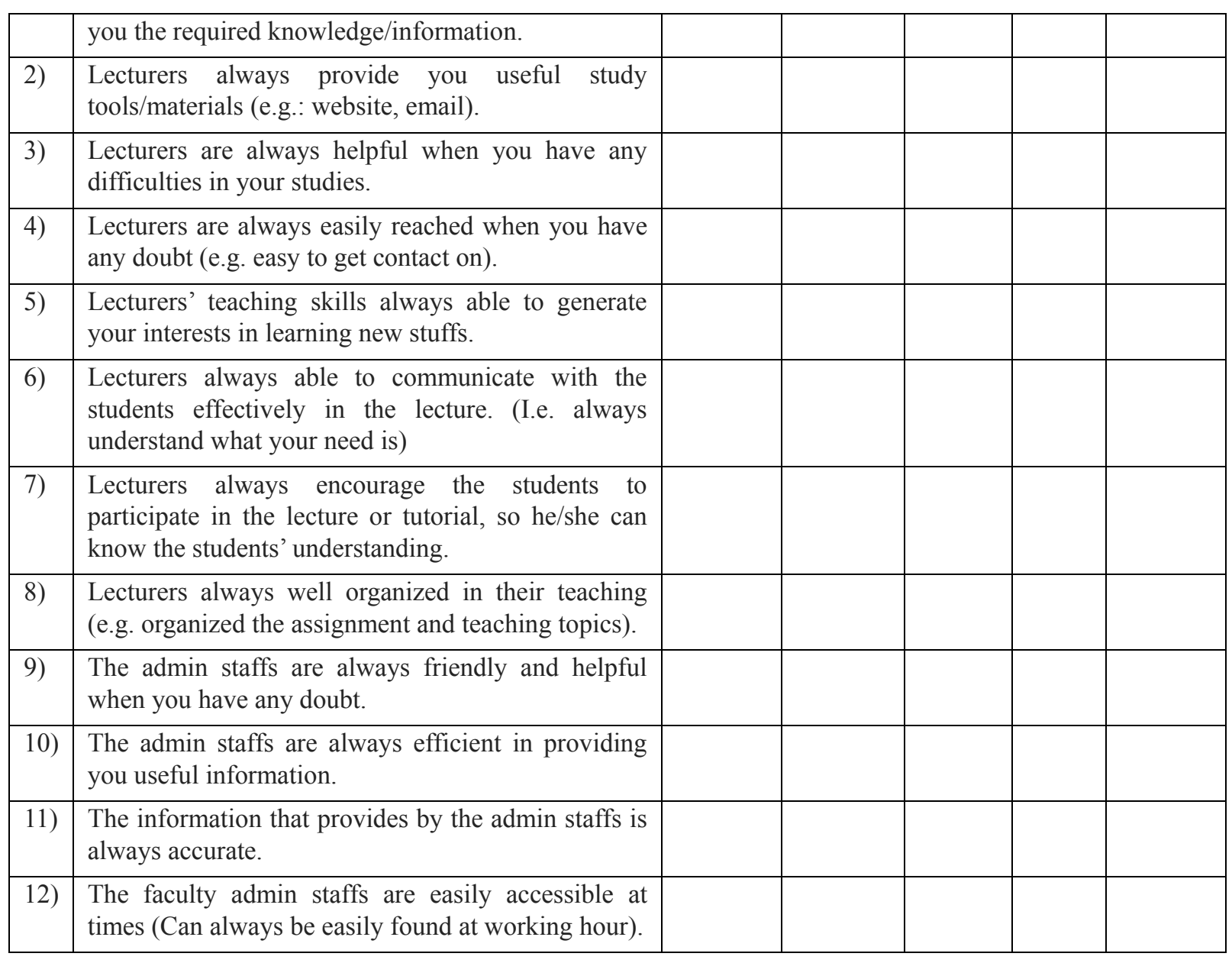

Part B: Curriculum Structure

\begin{tabular}{|c|c|c|c|c|c|c|}
\hline & & $\begin{array}{l}\text { Strongly } \\
\text { disagree }\end{array}$ & Disagree & Neutral & Agree & $\begin{array}{l}\text { Strongly } \\
\text { agree }\end{array}$ \\
\hline 13) & $\begin{array}{l}\text { UBD GENnext Program offers you varieties of } \\
\text { courses or modules in each semester. }\end{array}$ & & & & & \\
\hline 14) & $\begin{array}{l}\text { The modules offered by the UBD GENnext } \\
\text { Program are mostly your interest. }\end{array}$ & & & & & \\
\hline 15) & $\begin{array}{l}\text { The modules offered by the UBD GENnext } \\
\text { Program are useful for your future working } \\
\text { placement. }\end{array}$ & & & & & \\
\hline 16) & $\begin{array}{l}\text { The UBD GENnext Program provides you more } \\
\text { opportunity to explore to the outside world. (due to } \\
\text { the Discovery Year and other courses) }\end{array}$ & & & & & \\
\hline 17) & $\begin{array}{l}\text { The UBD GENnext programs is a well organize } \\
\text { programs structure. (I.e. The need to fulfill all the } \\
\text { requirements stated in the UBD GENnext Programs } \\
\text { rules and regulations.) }\end{array}$ & & & & & \\
\hline
\end{tabular}

Part C: Library Services

\begin{tabular}{|l|l|l|l|l|l|l|}
\hline & & $\begin{array}{l}\text { Strongly } \\
\text { disagree }\end{array}$ & Disagree & Neutral & Agree & $\begin{array}{l}\text { Strongly } \\
\text { agree }\end{array}$ \\
\hline
\end{tabular}




\begin{tabular}{|l|l|l|l|l|l|l|}
\hline 18) & $\begin{array}{l}\text { Library of UBD provide adequate educational } \\
\text { sources for academic and research program (books, } \\
\text { journals, referenced materials). }\end{array}$ & & & & & \\
\hline 19$)$ & $\begin{array}{l}\text { Library of UBD provide adequate facilities such as } \\
\text { computer lab, study rooms, computers. }\end{array}$ & & & & & \\
\hline 20$)$ & $\begin{array}{l}\text { Library of UBD website provide adequate } \\
\text { e-resources. (e.g. e-book and e-journals). }\end{array}$ & & & & & \\
\hline 21$)$ & $\begin{array}{l}\text { UBD librarians provide quality services in servings } \\
\text { the students. }\end{array}$ & & & & & \\
\hline 22$)$ & $\begin{array}{l}\text { Library of UBD provide quality environment for } \\
\text { students to do their work. }\end{array}$ & & & & \\
\hline
\end{tabular}

Part D: Environment

\begin{tabular}{|l|l|l|l|l|l|l|}
\hline & & $\begin{array}{l}\text { Strongly } \\
\text { disagree }\end{array}$ & Disagree & Neutral & Agree & $\begin{array}{l}\text { Strongly } \\
\text { agree }\end{array}$ \\
\hline 23) & $\begin{array}{l}\text { UBD provides you a quality environment for } \\
\text { studying. (Cafeteria, sport facilities, medical } \\
\text { facilities, library) }\end{array}$ & & & & & \\
\hline 24) & $\begin{array}{l}\text { UBD provide you all the necessary resources in } \\
\text { order to enhance your learning ability. (Classroom, } \\
\text { lab, projectors, Wi-Fi). }\end{array}$ & & & & & \\
\hline 25) & UBD has a high level of cleanliness. & & & & \\
\hline
\end{tabular}

Overall, how would rate the quality of education services (academic staff, curriculum structure, library services, and accommodation) provided by UBD?

$\square$ Very Poor

$\square$ Good

$\square$ Very Good

What possible measures would you suggested in improving the quality of education services in UBD?

\section{Copyrights}

Copyright for this article is retained by the author(s), with first publication rights granted to the journal.

This is an open-access article distributed under the terms and conditions of the Creative Commons Attribution license (http://creativecommons.org/licenses/by/3.0/). 